\title{
Student Self-Efficacy in Modular Accounting: A Tool to Improve the Academic Performance of Accounting Students Enrolled in the Modular Program of De La Salle University
}

\author{
Kim Gayle C. Auson, Madeleine Richel B. Cabigas, Rafael Josh B. Garay, Carl Noah Luis A. \\ Javier, Rodiel C, Ferrer
}

\begin{abstract}
Self-efficacy has been a concept which has been greatly explored and related to different fields, especially performance. However, various studies showed inconsistencies in the findings and mostly focused on academic performance, not taking into account other various control variables. This research aimed to provide information regarding the effects of selfefficacy in the academic performance of students in an academic setting while controlling for demographic and environmental factors. Particularly, it focused on the De La Salle University's Modular Program for Accountancy students. Employing a sample of 530 accounting students in De La Salle University, the results of the study found out that general self-efficacy has a significant impact on the academic performance of accounting students enrolled in the modular program. The study also found out that there are other significant variables that affected the academic performance of the students.
\end{abstract}

Keywords-Self-Efficacy, Academic Performance, Modular Program

\section{INTRODUCTION}

Bandura (1986) defined Self-efficacy as "beliefs in one's capabilities to mobilize the motivation, cognitive resources, and courses of action needed to meet given situational demands". This concept influences how people behave and make their decisions. Furthermore, Self-efficacy is a significant variable in an individual's thought-processing capability which leads to designated types of educational performances. The extent of the relationship of self-efficacy and academic performance can be studied through the unique modular program of De La Salle University. The institution has implemented the modular program which is composed of four modules wherein students are given four terms taking major accounting subjects only.

Revised Manuscript Received on August 14, 2019.

Kim Gayle C. Auson, Accountancy Department, De La Salle University - Taft Avenue, Manila City, Philippines. (E-mail: kim_auson@dlsu.edu.ph)

Madeleine Richel B. Cabigas, Accountancy Department, De La Salle University - Taft Avenue, Manila City, Philippines. (E-mail: madeleine_cabigas@dlsu.edu.ph)

Rafael Josh B. Garay, Accountancy Department, De La Salle University - Taft Avenue, Manila City, Philippines. (E-mail: rafael_garay@dlsu.edu.ph) University - Taft Avenue, Manila City, Philippines.(E-mail: carl_javier@dlsu.edu.ph)

Rodiel C, Ferrer Accountancy Department, De La Salle University Taft Avenue, Manila City, Philippines. (E-mail: rodiel.ferrer@dlsu.edu.ph)
Carl Noah Luis A. Javier, Accountancy Department, De La Salle

\section{A. Social Cognitive Theory}

Social Cognitive Theory (SCT) was developed based on the idea that several aspects such as cognitive, behavioral and environmental factors create a triadic interaction that have an impact on learning and achievement. One of the most important factors emphasized in SCT is self-efficacy because it has an impact on the way people act, feel, think and motivate themselves (Alci, 2015). The research also sees how one understands and believes in his skills in performing tasks. Thus, students with higher self-efficacy tend to accept challenging and difficult tasks readily than students with lower self-efficacy.

\section{B. Expectancy Theory}

Vroom (1964) defined the expectancy theory as a set of decision theories of work motivation and performance. The theory further tackles that a motivation of an individual depends on two factors which are the expectancies of receiving a reward and the perceived desirability or valence of receiving a certain kind of reward in exerting a level of effort.

\section{Self-Efficacy Theory}

Bandura (1994) stated in his self- efficacy theory than anyone, regardless of past circumstances and situations can effectively and has the ability to exercise and strengthen their self-efficacy, namely mastery experiences, social modeling, social persuasion, and states of physiology. Mastery experiences is experiencing the results of selfefficacy first hand. It was pointed out in his study that failure is important so that the researchers can build resilience to it. Social Modeling is a procedure wherein individuals will choose role-models that can demonstrate their self-efficacy. Social persuasion is all about finding for the right mentor. It is more specific than social modeling because it involves having others directly influence one's self-efficacy by providing opportunities, information, and other relevant data to increase one's experiences. Lastly, states of physiology is based on their current mood, emotions, and physical state of an individual. Positive and 


\section{STUDENT SELF-EFFICACY IN MODULAR ACCOUNTING: A TOOL TO IMPROVE THE ACADEMIC PERFORMANCE OF ACCOUNTING STUDENTS ENROLLED IN THE MODULAR PROGRAM OF DE LA SALLE UNIVERSITY}

negative emotions act as magnets to further influence one's sense of self-efficacy, especially in the case of a depressed mood when control can feel out of reach.

\section{Social Learning Theory (Locus of Control)}

This theory states that there are three general modes and concepts on which learning can occur. First is through observation of other people and learning from what you see. Second is through intrinsic reinforcement which explains that internal thoughts and cognition play an important role of learning through a reward-driven behavior. Last is Modelling in which an individual must observe a model, retain the behavior displayed by the model, replicate the said behavior and to be motivated in applying the behavior of the model in oneself. Rotters further added that there is an interplay between personality and the environment. (Kelland, 2015). Mearns (2017) said that a person with a strong internal locus will think that the rewards or consequences that they experienced was caused by themselves while those with a strong external locus would believe that the reinforcement was due to external factors like other individuals and luck.

\section{E. Research Objectives}

This study aspires to provide information regarding the effects of self-efficacy in the academic performance of students. The researchers' objectives are the following:

1) To provide information regarding the effects of selfefficacy in the academic performance of students.

2) To assess the effects and to determine the extent of self-efficacy, while other control variables exist, particularly accountancy students in De La Salle University enrolled in the modular program.

\section{F. Hypotheses}

The following hypotheses were formulated by the researchers to determine the extent of self-efficacy on the academic performance of accounting students enrolled in modular subjects:

\section{1) Regression Results}

Ho1: Self-efficacy does not have an impact on the academic performance of accountancy students enrolled in modular subjects in De La Salle University.

Ha1: Self-efficacy has an impact on the academic performance of accountancy students enrolled in modular subjects in De La Salle University.

Ho2: Demographic control variables such as gender, age, proximity to school, ethnicity and average hours of sleep do not have an impact on the academic performance of accountancy students enrolled in modular subjects in De La Salle University.

Ha2: Demographic control variables such as gender, age, proximity to school, ethnicity and average hours of sleep have an impact on the academic performance of accountancy students enrolled in modular subjects in De La Salle University.

Ho3: Accountancy curriculum control variables such as grade point average (GPA), course workload, and internship experience do not have an impact on the academic performance of accountancy students enrolled in modular subjects in De La Salle University.

Ha3: Accountancy curriculum control variables such as grade point average (GPA), course workload, and internship experience have an impact on the academic performance of accountancy students enrolled in modular subjects in De La Salle University.

Ho4: Background control variables such as family background, secondary education, and accounting subjects tackled in high school do not have an impact on the academic performance of accountancy students enrolled in modular subjects in De La Salle University.

Ha4: Background control variables such as family background, secondary education, and accounting subjects tackled in high school have an impact on the academic performance of accountancy students enrolled in modular subjects in De La Salle University.

Ho5: Degree Status control variables such as regularity in the curriculum, number of undergraduate college degrees, and internal transfer of course do not have an impact on the academic performance of accountancy students enrolled in modular subjects in De La Salle University.

Ha5: Degree Status control variables such as regularity in the curriculum, number of undergraduate college degrees, and internal transfer of course have an impact on the academic performance of accountancy students enrolled in modular subjects in De La Salle University.

Ho6: Non-academic control variables such as number of organizational involvements in the university, other extracurricular activities outside the university and involvement in a romantic relationship do not have an impact on the academic performance of accountancy students enrolled in modular subjects in De La Salle University.

Ha6: Non-academic control variables such as number of organizational involvements in the university, positions held in university organizations, other extracurricular activities outside the university and involvement in a romantic relationship have an impact on the academic performance of accountancy students enrolled in modular subjects in De La Salle University.

\section{2) T-Test/Analysis of Variance (ANOVA)}

Ho7:There are no significant differences in the mean academic performance when the respondents are grouped according to demographic profile (such as age, gender, proximity to school, ethnicity, and average hours of sleep)

Ha7:There are significant differences in the mean academic performance when the respondents are grouped according to demographic profile (such as age, gender, proximity to school, ethnicity, and average hours of sleep)

Ho8:There are no significant differences in the mean academic performance when the respondents are grouped according to accounting curriculum cluster (such as gpa, course workload, and internship) 
Ha8:There are significant differences in the mean academic performance when the respondents are grouped according to accounting curriculum cluster (such as gpa, course workload, and internship)

Ho9:There are no significant differences in the mean academic performance when the respondents are grouped according to background (such as family background, secondary education, and accounting subject in high school)

Ha9:There are significant differences in the mean academic performance when the respondents are grouped according to background (such as family background, secondary education, and accounting subject in high school)

Ho10:There are no significant differences in the mean academic performance when the respondents are grouped according to degree status (such as number of college degrees, regularity in the program, shifting status)

Ha10:There are significant differences in the mean academic performance when the respondents are grouped according to degree status (such as number of college degrees, regularity in the program, shifting status) academic performance when the respondents are grouped according to non-academic variables (such as number of organizational involvements in the university, positions held in university organizations, other extracurricular activities outside the university and involvement in a romantic relationship)

Ha11:There are significant differences in the mean academic performance when the respondents are grouped according to non-academic variables (such as number of organizational involvements in the university, positions held in university organizations, other extracurricular activities outside the university and involvement in a romantic relationship.

\section{LITERATURE REVIEW}

A vast number of literatures tackled on the role of selfefficacy in an academic setting. Studies found out the importance and effect of a student's self-efficacy in academic performance and findings showed that students which have higher self-efficacy tend to have better performance and grades. (Zimmerman 2000; Breso et. al 2010; Motlagh 2011).

\section{A. Self-Efficacy}

The concept of Self-efficacy and its construct was first introduced by Albert Bandura during 1977 and has led to different developments by other researchers since then. SelfEfficacy has been defined by Wood and Bandura as "people's belief in their capabilities to mobilize the motivation, cognitive resources and courses of action needed to exercise control over the event in their lives". (1989, as cited by Muretta, 2004).

Through time, self-efficacy can be developed through the four factors: Mastery Experience, Vicarious Experiences, Social Persuasion, and Emotional \& Physiological States according to Bandura (1994).

Mastery experience pertains to a person's need to directly undergo certain situations such as success and failure in order for the individual to develop self-efficacy. (Bandura, 1994).
Ho11:There are no significant differences in the mean

Conversely, Pajares (2002) has posited that indirect participation through observational learning or Vicarious experience would also help in the development of selfefficacy.

Persuasions also play a role in building self-efficacy as Bandura (1994) explained that when an individual is indecisive and hesitant in exerting effort in a certain tasks because of his capabilities, verbal persuasions can help in increasing the self efficacy in the task at hand which will result to the individual being more determined and motivated to succeed.

Physiological states refer to the bodily conditions of an individual relating to anxiety level, emotions and mood when put up in different situations. Pajares (2002) mentioned how these factors will cause discomfort, agitation and more pressure in having a successful outcome and in effect can lead to a negative outcome like failure. Moreover, having a positive mood and confidence can lead to higher self efficacy of oneself.

\section{B. Self-Efficacy and Academic Performance}

Various studies concluded that different factors affect one's academic performance and as evidenced by Ahmad \& Safaria (2013), one of these factors is self-efficacy. Breso et. al (2011) have acknowledged that there is an undeniable effect of self-efficacy on one's learning process which also boosts the comfort level and the wellbeing of a student, especially when they are taking tests. This was in line with the study of Bandura (1997) which found out that selfefficacy beliefs also contribute to student academic performance as they influence thought, process, motivation, and behavior. (As cited by Kolo, Jaafar, and Ahmad, 2017). Further, Dull, Shleifer and McMillan (2015) suggested that those students who have high grade expectations and higher self-efficacy obtained higher grades compared to those students who got lower grades because they had lower grade expectations and lower self-efficacy. These findings are similar with the outcomes of the study of Shahid, Jabeen and Ansari (2016), as they found out that self-efficacy and academic performance have a positive relationship, strengthening prior claims that a student who has a high self-efficacy tend to have high grades in their academic performance.

\section{Other Determinants}

Although various literatures have consistently suggested that self-efficacy is a predictor of performance, it can be inferred that this alone does not entirely determine the performance of the subjects. Factors including demographic variables, cumulative GPA, whether a student is an accounting major or not, whether the student is repeating the course or not and whether where the introductory class was taken (university level or junior college) as per Turner et al. (1997) were significant predictors of academic performance..

Burnett et. al (2010) explained how demographic variables are commonly seen in studies relating to performance because it was found out that these variables

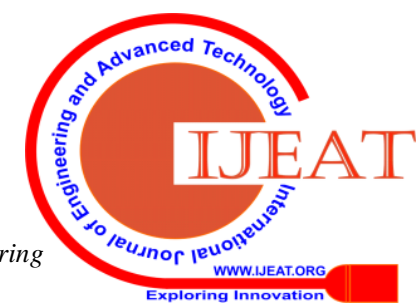




\section{STUDENT SELF-EFFICACY IN MODULAR ACCOUNTING: A TOOL TO IMPROVE THE ACADEMIC PERFORMANCE OF ACCOUNTING STUDENTS ENROLLED IN THE MODULAR PROGRAM OF DE LA SALLE UNIVERSITY}

are good predictors of performance. Gould (1981) shows how demographic variables such as age, gender, race and socioeconomic status are used to measure intelligence. Similarly, sge, course load, gender, and marital status are found to be important predictors in introductory accounting (Frakes, 1977).

Bandura et. al (2012) used the cumulative grade point average (CGPA), course workload, and work experience in determining their effects to an accounting student's academic performance, which proved to be significant predictors. Cumulative grade point average and course workload were also used by Clark \& Latshaw (2011) to measure the factors affecting student performance in an introductory accounting class.

High school exposure to accounting influenced academic performance in college according to Eskew and Faley (1988). Smith (1968) had similar findings where he found out that students who had high school accounting experience could successfully complete basic accounting in college in substantially less time than those who had no experience.

Turner et. al (1997) have posited that repeating an accounting subject and withdrawing from the course are some of the factors affecting the academic performance of an accounting major student. In contrast, the study of Erer (2017) found out that there is no significant relation between accounting course grades and the semester course load, gender, and the repeating the course.

Other possible determinants as Holland and Andre (1987) mentioned, include participation in extracurricular activities. Marsh (1992) also suggested that as participation in ECAs leads to commitment to school and school values, an increased academic success is indirectly achieve.

\section{METHODOLOGY}

A causal-explanatory research is used in this study. This type of research design will enable the researchers to determine the impact of one variable to another. With this, the research objective of determining the impact of selfefficacy in consideration of the existence of different external factors to a student's academic performance will be answered. This study will employ the use primary data through questionnaires to gather the responses of the selected population. This will also be a quantitative research. The study will quantify the variables by employing structured questions and apply statistical analysis in measuring the data gathered from the respondents.

\section{A. Population and Respondents}

The population of the study will consist of accountancy students in De La Salle University who were enrolled in Term 3, academic year 2016-2017 and Term 1 academic year 2017-2018 under the following modular subjects: Module 1 (Financial Accounting and Cost Accounting), Module 2 (Advanced Accounting, Auditing Principles and Information Systems), Module 3 (Auditing Problems, Thesis, Practicum and Management Accounting) and Module 4 (Integrated Review of CPA board exam subjects). Those students who will voluntarily participate through a survey administered online will serve as the respondents for this study. Moreover, the population is limited to students

who were admitted by the university from years 2012 to 2016 only.

\section{B. Sampling Design}

The population of the study will be gathered through the list of Accountancy students in the modular program from the Accountancy Department of De La Salle University. Since the population of the study is only five hundred and thirty (530), it is practical and advantageous to employ total enumeration wherein each element of the population will be included in the sample.

\section{Research Procedures}

The researchers will first determine the sample size by using total enumeration using the list of the students enrolled in Term 3 of the Academic Year 2016-2017 and Term 1 of the Academic Year 2017-2018 in the different modules that is provided for by the accountancy department of De La Salle University.

After obtaining the list, the researchers will then give out questionnaires through online survey platforms like google forms and survey monkey. This will aid the researchers collect and summarize the data at the same time, because these platforms automatically transmit the information to the cloud and summarize the given data. The questionnaire will mainly be composed of questions and situations about selfefficacy and its effects in the academic performance of each student. The researchers plan to have a "Motivated Strategies for Learning Questionnaire" (MLSQ) a 5-point Likert scale in the different questions and situations about self-efficacy (Pintrich et. al, 1991). This questionnaire will focus on the measure of self-efficacy so that the results can be used to know the effects of self-efficacy to the academic performance of accounting students in De La Salle University. Lastly, the different variables in each cluster such as demographic, curriculum requirements, background, degree status, and non-academic clusters will be questioned directly.

Lastly, with the data provided, this study will implement different data analysis techniques such as descriptive statistics, regression analysis, OLS regression, analysis of variance and paired t-test.

\section{Data Analysis}

\section{1) Descriptive Statistics}

Descriptive statistics can be categorized into three measures which includes the distribution of data, measures of central tendency and the variability of data. The first measure of descriptive statistics aims to show how variables of the study are distributed for a defined range or category. Applying this into the study, the frequency of given values relating to a certain category would be presented. Another measure to be utilized is the central tendency. In simple words, measures of central tendency would want to define or estimate the "center" of the distribution of a given dataset. Some of the central tendency measures the study would want to use are mean, median and mode. Lastly, the 
variability of data measure the researchers would want to employ is Standard Deviation which is computed using this formula:

\section{2) OLS Regression}

Ordinary Least Square Linear Regression is a way of measuring "accuracy" and gives a rule for how precisely to choose the best constraints. The Least squares method is used to choose these best constraints so that for every example point in the data, the researchers may minimize the sum of the squared differences between the actual dependent variable and the predicted value for the dependent value.

\section{3) Paired T-Test}

A paired t-test is used when a study has two related observations and the researchers want to see if the means on these two normally distributed interval variables differ from one another. The researchers can know if the means of the variables stated in this study will significantly differ from one another. It is important to know such fact so that the researchers can separate the means of the variables that are statistically significantly different. It can be an important factor that can either support the researchers' hypotheses or contradict it.

\section{4) Analysis of Variance (ANOVA)}

ANOVA is used in determining whether there are significant statistical differences in the mean of three or more independent groups. It is used when an independent variable (with two or more categories) and a normally distributed interval dependent variable and a need to test for differences in the means of dependent variable broken down by the levels of the independent variable. ANOVA is a vital test for this study since it has numerous variables. The researchers want to enumerate the variables with significant differences and check the reason why this variables differ.

\section{E. A Priori Expectation}

In terms of the impact of self-efficacy to academic performance and in accordance with Burnett et. al (2010)'s results, the researchers expect self-efficacy to have a positive impact on academic performance. Furthermore, the researchers expect that academic performance is not affected by self-efficacy alone. As mentioned by past studies, there are other predictors and determinants affecting academic performance. Some predictors which the researchers expect to affect performance are curriculum cluster variables such as cumulative GPA, course workload and internship experience (Turner et al. 1997; Christensen et al. 2002; Bandura et al., 2012), demographic variables relating to gender, race (Frakes, 1977; Gould, 1981; Burnett et al., 2010), background variables pertaining to previous accounting experience in high school (Eskew et al., 1988; Smith, 1968), other extracurricular activities including church involvement (Marsh, 1992) and physical activity (Eidsmore, 1964; Schafer and Armer, 1968).

\section{RESULTS, FINDINGS, AND DISCUSSION}

The researchers used descriptive analysis (independent variables analysis and control variables analysis), regression model, t-tests, and analysis of variance in order to come up with comprehensive results that will meet the objectives of the study.

The study found out that general self-efficacy, accounting subject in high school, JPIA involvement, and online games have significant impacts on the academic performance of the students in the modular program of De La Salle University. Other variables under the demographic cluster, accounting curriculum cluster, background cluster, degree status cluster, and non-academic cluster provided in the conceptual framework, other than those mentioned above, proved to be insignificant.

While analyzing the results of the study, the researchers found out that each significant variable affects a specific module in the study. General self-efficacy has a significant impact on modules 2, 3, and 4. Accounting in high school has a significant impact on module 2. Next, JPIA involvement affects only modules 1,2 , and 4 while on the other hand, online games have a significant impact on module 4 . These findings are in line or contrasting with past researchers, theses, and studies.

Furthermore, the researchers met the objectives of the study and proved that self-efficacy affects the academic performance of the student. It can be used as a tool in order to improve a student's academic performance in universities, schools, and other academe-related institutions.

\section{A. Findings}

The researchers divided the descriptive analysis into two parts: independent variable analysis and control variables analysis. The main test of the study are conducted using the regression model, and are confirmed with t-tests and analysis of variance (ANOVA).

Table I Summary of Descriptive Statistics (Independent Variable Analysis)

\begin{tabular}{|l|c|c|}
\hline \multicolumn{1}{|c|}{ Variable } & Highest Mean & Lowest Mean \\
\hline $\begin{array}{l}\text { Academic } \\
\text { Performance }\end{array}$ & Module 1 & Module 3 \\
\hline $\begin{array}{l}\text { Specific Self- } \\
\text { Efficacy }\end{array}$ & Module 2 & Module 3 \\
\hline $\begin{array}{l}\text { General Self- } \\
\text { Efficacy }\end{array}$ & Module 1 & Module 4 \\
\hline
\end{tabular}

With the data presented in Table 1, it can be observed that the highest mean for the dependent variable, which is academic performance, is in module 1 . This implies that students who are taking module 1 performed better academically compared to students who are taking other modules in the accountancy program of De La Salle University.

It can also be observed that the highest mean among the modules for one of the parts of the independent variable, which is specific self-efficacy, is seen in module 2. This implies that students who are studying module 2 have higher 


\section{STUDENT SELF-EFFICACY IN MODULAR ACCOUNTING: A TOOL TO IMPROVE THE ACADEMIC PERFORMANCE OF ACCOUNTING STUDENTS ENROLLED IN THE MODULAR PROGRAM OF DE LA SALLE UNIVERSITY}

specific self-efficacy compared to students who are taking other modules. It can also be implied that module 3 has the lowest mean for specific self-efficacy which can be linked to why it has the lowest academic performance mean. Specific self-efficacy is the self-efficacy of students towards the modular program of De La Salle University. It is based on the syllabus of each course in the modular program. On the other hand, general self-efficacy is based on the "Motivated Strategies for Learning Questionnaire" (MLSQ), a 5-point Likert scale in the different questions and situations about self-efficacy made by Pintrich et. al (1991).

Lastly, it is observed that the highest mean among the modules for the other part of the independent variable, which is general self-efficacy, can be seen in module 1 This implies that students in module 1 have the highest general self-efficacy which was measured by the "Motivated Strategies for Learning Questionnaire" compared to students who are taking other modules.

Table II Summary of Descriptive Statistics (Control Variables Analysis)

\begin{tabular}{|l|c|}
\hline \multicolumn{1}{|c|}{ Variable } & $\begin{array}{c}\text { Higher General Self- } \\
\text { Efficacy }\end{array}$ \\
\hline Age & Males \\
\hline Gender & years old and below \\
\hline Hours of Sleep & With internship \\
\hline Internship & $0-2$ Siblings \\
\hline No. of Siblings & With CPA in the family \\
\hline Background & Outside Metro Manila \\
\hline Secondary Education & Regular \\
\hline Regularity in the course & Non-shiftee \\
\hline Shifting Status & Double Degree \\
\hline No. of Degrees & JPIA Involvement \\
\hline Org. Involvement & Serious Relationship \\
\hline Relationship Status & \\
\hline
\end{tabular}

These are the main findings of the descriptive statistics of the study. The variable that has the higher or highest average mean when it comes to the students' general self-efficacy are indicated in Table 2. It can be seen that males have higher general self-efficacy than females. This supports the study conducted by Shahid and Mohammadyari which found out that women tend to be more anxious academically which results to lower self-efficacy. Their study also states that men tend to be more confident, leading to a higher selfefficacy.

Kelly, Kelly \& Clanton (2001) confirmed the results of this study, wherein students who have more sleep tend to have higher self efficacy than short sleepers. Also, Hutaibat
(2011) found out that students who have a CPA family member are becoming more interested in the profession. Therefore, confirming the results of this study.

Table III Summary of Regression Results

\begin{tabular}{|c|c|c|c|c|c|}
\hline & Variable & Coefficient & T-Value & P-Value & $\begin{array}{c}\text { Verbal } \\
\text { Interpretation }\end{array}$ \\
\hline \multirow{4}{*}{ Module 1 } & (Constant) & 1.926 & 5.470 & .000 & \\
\cline { 2 - 6 } & SE-Specific & .094 & 1.087 & .279 & Insignificant \\
\cline { 2 - 6 } & SE-General & .073 & .759 & .449 & Insignificant \\
\hline \multirow{4}{*}{ Module 2 } & (Constant) & 1.643 & 4.639 & .000 & \\
\cline { 2 - 6 } & SE-Specific & .008 & .087 & .931 & Insignificant \\
\cline { 2 - 6 } & SE-General & .241 & 2.741 & .007 & Significant \\
\hline \multirow{3}{*}{ Module 3 } & (Constant) & 1.052 & 3.146 & .002 & \\
\cline { 2 - 6 } & SE-Specific & -.005 & -.059 & .953 & Insignificant \\
\cline { 2 - 6 } & SE-General & .397 & 3.961 & .000 & Significant \\
\hline \multirow{2}{*}{ Module 4 4 } & (Constant) & 1.602 & 3.703 & .000 & \\
\cline { 2 - 6 } & SE-Specific & -.057 & -.513 & .609 & Insignificant \\
\cline { 2 - 5 } & & & &
\end{tabular}

The self-efficacy variable is further subdivided into two specific self-efficacy and general self-efficacy. Table 3 presents the summary of regression results of the impact of specific and general self-efficacy to the academic performance of the students. General self-efficacy under Module 2 (coefficient=.241, $\mathrm{t}=2.741, \quad \mathrm{p}=.007$ ), 3 (coefficient $=.397, \mathrm{t}=3.961, \mathrm{p}=.000)$ and 4 (coefficient $=.321$, $\mathrm{t}=2.365, \mathrm{p}=.020$ ) proved to be significant because it has a $\mathrm{p}$ value of less than 0.05 . It is also confirmed that the results of the test are correct since these three variables have higher t-values compared to other variables. In summary, the general self-efficacy of the students towards classes significantly affects their academic performance. This is consistent with the studies made by Becker (2009) and Shkullaku (2013) where general self-efficacy has a significant impact in the students' academic performance. According to Bandura et al., (1996); Bandura (1997), general self-efficacy are more predictive and account for substantially more of the variance in academic achievement. However, it can be noticed that general gelf-efficacy affects Modules 2, 3, and 4 only, having insignificant results in Module 1. A possible explanation of this occurrence could be attributed to experience. Entering into the first Module of the accountancy program, students have little experience and varying expectations on what it is like taking the module. Therefore, it could occur that these students might have assessed their self-efficacies too high or too low which ultimately resulted to be an inaccurate predictor of academic performance. Conversely, students in the higher module programs already have previous modular experience which enables them to set a self-efficacy which substantially reflects their performance.

Also, students in Module 2 who had accounting in high school tend to have a better academic performance than those who did not. HS Accounting in Module 2 also showed the highest $\mathrm{t}$-value, proving the alternative hypothesis more than the null. Result on the significance of HS Accounting on the students' academic performance supports the findings of Eskew and Faley (1988) and Smith (1968) as they have 
fathomed that accounting exposure in high school enabled better academic performance in college. It also supported the study of Authors (2016) which found out that students with prior accounting subjects, particularly in high school, are getting better grades compared to those who do not have prior accounting subjects.

Being involved in the course's professional organization, Junior Philippine Institute of Accountants (JPIA), shows a significant effect in Module 1, Module 2 and Module 4. However, Module 3 showed that JPIA involvement does not have a significant impact on academic performance. This is consistent with the findings of Nwanko \& Okoye (2015) which explained that a student's involvement in his/her course's professional organization tends to have an impact on his/her academic performance because the professional organization serves as a ground for the student to stimulate and cultivate his/her interest towards her course. Thus, this interest will be reflected on how well he/she will perform in his/her academics, in this case, his/her accounting subjects. Moreover, a study by Foubert \& Grainger (2006) explained that both sophomores and seniors involved in school organizations reported a significant impact in their academics compared to freshmen and juniors because they tend to be more involved and interested in joining organizations. This may explain why Module 3 students, who are on their later sophomore or early junior year, do not result to organizations not having a significant impact on academic performance.

Online Games significantly affects the performance of Module students. Moreover, results show a negative coefficient for Online Games which may suggest that when students spend more time on playing online games, they get lower grades in Module 4. The significant results on Module 4 could be compared to similar studies such as Sharif and Sargent's (2010) which concluded that there are adverse effects on school performance as caused by online gaming among students aged 10-14. In relevance to the age group of this study, Norris (2010) also suggested that excessive internet use, which involves online gaming, is negatively associated with performance, particularly with reading and vocabulary among students aged 14-22. This may explain how frequency or extent of internet usage with regard to online games could significantly affect performance. Putting it into context of the results, students from Modules 1, 2, and 3 have not exhibited an excessive online gaming engagement which lead to the results being insignificant, whereas this may suggest that Module 4 students exhibited the contrary, although more study focusing on this should be done to validate.

\section{CONCLUSIONS AND RECOMMENDATIONS}

\section{A. Conclusions}

The researchers were able to provide the impact of self efficacy to academic performance of modular students using the regression analysis on a per modular basis and on an aggregate basis. The study managed to determine the effect of various control variables namely Demographics, Accountancy Curriculum, Degree Status, Background, and Non-Academic variables to academic performance while reaffirming and contradicting different studies conducted in the past.

\section{1) Self-efficacy and Academic Performance}

General self-efficacy of modular students in the modular program towards classes significantly affects their academic performance. This result was in line with the findings of the studies conducted by Becker (2009) and Shkullaku (2013) where general self-efficacy had a significant impact in the students' academic performance.

\section{2) Demographic Variables and Academic Performance}

Male students in the modular program had a higher mean for general self-efficacy than female modular program students because women tend to have more anxiety than males (Mohammadyari, 2012). This affected the perception of females of their ability to fulfill tasks at hand, especially in terms of academics. Furthermore, findings of the study showed that demographic control variables do not significantly affect the academic performance of modular program students, given the special setting and fast paced nature of the modular program compared to introductory accounting. Lastly, there were no significant differences in the academic performance of students when grouped according to sleep hours for Modules 1, 3 and 4 but have shown a significant difference in Module 2 which suggests that students who sleep 7 to 9 hours daily during Module 2 would tend to have better grades than those who sleep less.

\section{3) Accounting Curriculum and Academic Performance}

Prior Work Experience do not have a significant impact on academic performance. This may be due to the limited time given to the modular students in DLSU because only 160 hours are allotted for their internship. Kolb (1984) explained that due to the limited time, students were not able to fully reflect on the application of their work experiences on their academic subjects. Another variable, the course workload, was not considered because all the student in each module are receiving the same amount of workload. Hence, this would not be a good predictor of academic performance.

\section{4) Background and Academic Performance}

Most background variables do not have a significant effect on the student's academic performance. However, one variable namely accounting subject in high school proved to be an indicator of a student's academic performance. Eskew and Faley (1988) have fathomed that accounting exposure in high school enabled better academic performance in college. However, forty percent who answered that they have an accounting subject in their secondary education have lower general self-efficacy than those who do not have an accounting subject in high school.

\section{5) Degree Status and Academic Performance}

Regular students, double degree students and non-shiftees had more variability in the responses than their counterpart for their general self-efficacy. Foraker (2012) suggested that the insignificant result was true when shifting occurs in 


\section{STUDENT SELF-EFFICACY IN MODULAR ACCOUNTING: A TOOL TO IMPROVE THE ACADEMIC PERFORMANCE OF ACCOUNTING STUDENTS ENROLLED IN THE MODULAR PROGRAM OF DE LA SALLE UNIVERSITY}

early years, but can have significant impact when done after two years due to the adjustment to another program. The researchers were not able to verify when the shiftees in the modular students have shifted, which can be a limitation of the study for a more accurate conclusion.

\section{6) Non-academic Variables and Academic Performance}

Organizational involvement results suggest that number of organizations alone do not significantly affect academic performance in all the modules. Conversely, JPIA involvement proved to be a predictor of performance in Modules 1, 2, and 4. The said organizational involvement variable also exhibited a positive coefficient which means JPIA involvement for Module 1, 2, and 4 students help them perform better. Nwank \& Okoye (2015) posited that being involved in a professional organization of the students' degree program would cultivate their interest which then would translate to better academic performance. Romantic relationship variables (Involved in Serious Relationship and Involved in Non Serious Relationship) showed no significant results across all modules either at the individual level or the group level. Results on most of the extracurricular variables pertaining to time spent on partying, working out, using social media, watching movies or TV, playing online games and church involvement showed no significance. Online games in module 4 is the only variable which showed significance with a negative coefficient which effectively suggest that more of online games would translate to a poorer academic performance in module 4

\section{B. Recommendations}

\section{1) Academic Institution}

Since this study proved that general self-efficacy has a significant effect in the academic performance of the students, the academic institution behind the students welfare should consider to conduct more researches on how they can fully integrate the self-efficacy of the students in their curriculum. The academic institution is encouraged to expand the research by extending the scope and variables of the study. They should apply the importance of self-efficacy to different colleges, different year levels, and different types of students. The academic institution can also advise its instructors, professors, and different stakeholders to incorporate different teaching styles in order to boost the self-efficacy of the students. The academic institution is encouraged to research on and implement different activities, games, classroom policies, school policies, and different school-related activities that will further boost students' motivation and self-efficacy, improving their academic performance in their classes. Lastly, the academic institution is encouraged to modify the different course syllabi and incorporate different plans on how the morale, motivation, and self-efficacy of the students will improve.

\section{2) Students}

Students should carefully consider the various variables studied to evaluate whether these affect how they perform academically. Thus, this could serve as a tool for students to improve on their performance. Moreover, since this paper supported a lot of past studies which found out that selfefficacy affects the academic performance of the students, they should learn to expose themselves to activities that might raise and strengthen their self-efficacy to help them perform better academically. Students should involve themselves in activities and programs which would boost their confidence that they can really perform well and deal with any academic-related tasks. As a result, this would improve their academic performance as proven by the study.

\section{3) Instructors}

The results of self-efficacy having a significant impact on academic performance can be used by professors and instructors to enhance their teaching style by incorporating methods coming from the self-efficacy theory, social learning theory, social cognitive theory, and expectancy theory, that can boost the self-efficacy of the students or their students' beliefs about their capabilities to perform well in the subjects of modular program. Furthermore, instructors can promote the involvement in the professional organization of Accountancy in DLSU namely the Junior Philippine Institute of Accountants (JPIA) which has a significant positive impact to the academic performance and GPA of the modular program students. Lastly, the instructors can propose a more integrative and comprehensive experience to the internship program of Accountancy students considering that the limited time can be a factor to the insignificant result of such variable to the academic performance of a student because of not being able to fully grasp their of their work experiences in application to their academic subjects.

\section{4) Government Agencies}

The different government agencies in charge of the welfare students like the Commission on Higher Education (CHED) and the Department of Education (DepEd) are encouraged to come up with different school mandated policies that will enhance the students' self-efficacy, motivation, and belief in oneself. It is encouraged for them to create regulations and legislations which would reform the approach of the current learning framework to better the address the needs of ever-changing landscape of education field and its stakeholders. It is also encouraged for them to run their own research about how the self-efficacy of the students affect their academic performance. It can be a national cause and implementation. It just might save the students from failing the different classes they are currently into.

\section{5) Society}

Apart from the results of this study, important human behavior concepts like self-efficacy, were discussed in length which the general public could use not only to better understand people but also to improve their lives. Results showing the different determinants of performance (General Self-Efficacy, JPIA Involvement), their effects and why those effects happen empowers society. With these information, the general public are encouraged to utilize them to their performance advantage. However, it remains a 
fact that some in the society are unable to benefit from this study due to various conditions. Therefore, those who can are empowered to share knowledge and information to those who cannot as the goal of a progressive society is to uplift each member.

\section{6) Future Researchers}

It was found out that only general self-efficacy had a significant effect on the academic performance of modular students. It was also found out that majority of the control variables were not able to have a significant impact on the academic performance. With these, future researchers may further continue this study by considering a wider scope through a longer time frame and a bigger set of respondents. Doing this may result to further strengthen or contradict this study. Moreover, a wider scope of stakeholders may benefit on the study. Future researchers could also dwell on other control variables not considered in this study to prove if these variables are able to significantly affect academic performance. Lastly, future researchers might also consider the impact of the independent variables used in this study on non-academic performance as there is a limited number of past researches which focused on this topic.

\section{REFERENCES}

1. Ahmad, A., \& Safaria, T. (2013). Effects of Self-Efficacy on Students' Academic Performance. Journal of Educational, Health and Community Psychology, 2(1). Retrieved from https://www.researchgate.net/publication/263162945_Effects_ of_Self-Efficacy_on_Students'_Academic_Performance.

2. Alci, B. (2015). The Influence of Self-Efficacy and Motivational Factors on Academic Performance on General Chemistry Course: A Modelling Study. Academic Journals, 10(4), 453-461. doi:10.5987/ERR2014.2003

3. Bandura, A. (1977). Self-efficacy: Toward a unifying theory of behavioral change. Psychological Review, 84(2), 191-215. doi:10.1037/0033-295X.84.2.191

4. Bandura, A. (1986). Social foundations of thought and action: A social cognitive theory. Englewood Cliffs, NJ: PrenticeHall.

5. Bandura, A. (1994). Self-efficacy. In V. S. Ramachaudran (Ed.), Encyclopedia of human behavior (Vol. 4, pp. 71-81) New York: Academic Press. (Reprinted in H. Friedman [Ed.], Encyclopedia of mental health. San Diego: Academic Press, 1998).

6. Becker, S., \& Gable, R. (2009). The Relationship of SelfEfficacy and GPA, Attendance, and College Student Retention. NERA Conference Proceedings 2009. Retrieved from

http://opencommons.uconn.edu/cgi/viewcontent.cgi?article=1 003\&context $=$ nera_2009

7. Bresó, E., Schaufeli, W., \& Salanova, M. (2011). Can a selfefficacy-based intervention decrease burnout, increase engagement, and enhance performance? A quasi-experimental study. Higher Education, 61(4), 339-355. Retrieved from http://0-www.jst or.org.lib1000.dlsu.edu.ph/stable/41477800

8. Burnett, R., Xu, L., \& Kennedy, S. (2010). Student Self Efficacy in Intermediate Accounting: A Tool to Improve Performance and Address Accounting Change. The Accounting Educators' Journal, 20, 109-134. Retrieved from www.aejournal.com/ojs/index.php/aej/article/download/167/9 4

9. Christensen, T. B., Fogarty, T. J., \& Wallace, W. A. (2002) The association between the directional accuracy of selfefficacy and accounting course performance. Issues in Accounting Education, 17(1), 1+. Retrieved from o.galegroup.com.lib1000.dlsu.edu.ph/ps/i.do?p=GPS\&sw=w
$\& \mathrm{u}=\mathrm{dlsu} \& \mathrm{v}=2.1 \& \mathrm{it}=\mathrm{r} \& \mathrm{id}=\quad$ GALE $\% 7 \mathrm{C}$

A83993649\&asid=64f6234b8dd2ea0fbaf6af652f3daf0e

10. Clark, S. D., \& Latshaw, C. A. (2012, Winter). "Peeling the onion" called student performance: an investigation into the factors affecting student performance in an introductory accounting class. Review of Business, 33(1), 19+. Retrieved from o.galegroup.com.lib1000.dlsu.edu.ph/ps/ i.do?p=GPS \&sw=w\&u=dlsu\&v=2.1\&it=r\&id= GALE\%7C A326656943\&asid=5838a5f 9f193c7dfcccdab0791d33370

11. Dull, R. B., Schleifer, L. F., \& McMillan, J. J. (2015). Achievement Goal Theory: The Relationship of Accounting Students' Goal Orientations with Self-efficacy, Anxiety, and Achievement. Accounting Education, 24(2), 152. doi:10.1080/09639284.2015.1036892

12. Eskew, R., \& Faley, R. (1988). Some Determinants of Student Performance in the First College-Level Financial Accounting Course. The Accounting Review, 63(1), 137-147. Retrieved from www.jstor.org.lib1000.dlsu.edu.ph/stable/247684

13. Foraker, M. (2012). Does Changing Majors Really Affect the Time to Graduate? The Impact of Changing Majors on Student Retention, Graduation, and Time to Graduate. 1-22. Retrieved March 19, 2018, from https://www.wku.edu/instres/documents/air_major_change.pd f.

14. Frakes, A. (1977). Introductory Accounting Objectives and Intermediate Accounting Performance. The Accounting Review,52(1), 200-210. Retrieved from http://0www.jstor.org.lib1000.dlsu.edu.ph/stable/246043

15. Gould S.J. (1981). The Mismeasure of Man. New York, NY W.W Norton \& Co.

16. Holland, A., \& Andre, T. (1987). Participation in Extracurricular Activities in Secondary School: What Is Known, What Needs to Be Known? Review of Educational Research, 57(4), 437-466. Retrieved from http://0 www.jstor.org.lib1000.dlsu.edu.ph/sta ble/1170431.

17. Kelland, M. (2015). Social Learning Theory and Personality Development. Retrieved October 27, 2017, from https://webcache.googleusercontent.com /search?q=cache:Hc9H4X7jAi4J:https://cnx.org/exports/4777 297e-118f-463e-9f14-35cec5ea0d94\%401.pdf/learningtheory-and-personality-development-1.pdf $\& \mathrm{~cd}=1 \& \mathrm{hl}=\mathrm{en} \& \mathrm{ct}=\mathrm{clnk} \& \mathrm{gl}=\mathrm{ph}$.

18. Kolb, D. (1984). Experiential Learning: Experience as the Source of Learning and Development. Englewood Cliffs, NJ: Prentice Hall.

19. Kolo, A., Jaafar, W., \& Ahmad, N. (2017). Relationship between Academic Self-efficacy Believed of College Students and Academic Performance. IOSR Journal Of Humanities And Social Science, 22(1), 75-80. Retrieved from https://www.researchgate.net/publication/313315847_Relatio nship_between_Academic_Self-

efficacy_Believed_of_College_Students_and_Academic_Perf ormance.

20. Marsh, H. W. (1992). Extracurricular activities: Beneficial extension of the traditional curriculum or subversion of academic goals?. Journal Of Educational Psychology, 84(4), 553-562. doi:10.1037/0022-0663.84.4.553Mearns, J. (2017). The Social Learning Theory of Julian B. Rotter. Retrieved from http://psych.fullerton.edu/jmearns/rotter.htm

21. Mohammadyari, G. (2012). Comparative Study of Relationship between General Perceived Self-efficacy and Test Anxiety with Academic Achievement of Male and Female Students. Procedia - Social and Behavioral Sciences, 2119-2123. Retrieved March 26, 2018, from https://www.sciencedirect.com/science/article/pii/S187704281 $205642 X$. 
STUDENT SELF-EFFICACY IN MODULAR ACCOUNTING: A TOOL TO IMPROVE THE ACADEMIC PERFORMANCE OF ACCOUNTING STUDENTS ENROLLED IN THE MODULAR PROGRAM OF DE LA

SALLE UNIVERSITY

22. Nwankwo, M. C., \& Okoye, K. R. (2015). Influence of college club in increasing student's interest and achievement in Nigerian post-primary schools as perceived by science students

23. Pajares (2002). Overview of social cognitive theory and of self-efficacy. Retrieved November 25, 2017 from http://www.emory.edu/EDUCATION/mfp/eff.html.

24. Pintrich, R. R., \& DeGroot, E. V. (1990). Motivational and self-regulated learning components of classroom academic performance, Journal of Educational Psychology, 82, 33-40.

25. Shahid, R., Jabeen, N., \& Ansari, N. (2016). Academic SelfConcept and Academic Achievement Among Undergraduates in Universities of Pakistan: A Gender Perspective. Retrieved from

http://sujo.usindh.edu.pk/index.php/SUJE/article/viewFile/232 9/1984.

26. Shkullaku , R. (2013). The Relationship between Self efficacy and Academic Performance in the Context of Gender among Albanian Students. European Academic Research, 1(4), 467-478. Retrieved from http:// euacademic.org/UploadArticle/33.pdf

27. Smith, J. (1968). Articulation of high school bookkeeping and college elementary accounting, Ph.D. dissertation, University of Oklahoma.

28. Turner, J. L., Holmes, S. A., \& Wiggins, C. E. (1997). Main article: Factors associated with grades in intermediate accounting. Journal of Accounting Education, 15269-288. doi:10.1016/S0748-5751(97)00002-X.

29. Vroom, V. H. (1964). Work and motivation. San Francisco, CA: Jossey-Bass.

30. Zimmerman, B. J. (2000). Self Efficacy: An Essential Motive to Learn. Retrieved from http://citeseerx.ist.psu.edu/viewdoc/download;jsessionid= ?doi=10.1.1.369.5846\&rep=rep1\&type $=$ pdf 